\title{
Performance Evaluation of Crushed Glass in Stabilizing Lateritic Soil for Road Pavement Layers
}

\author{
Akanbi $\mathrm{DO}^{1^{*}}$, Sule $\mathrm{E}^{2}$, Achema $\mathrm{F}^{2}$, Bakam $\mathrm{VA}^{2}$ \\ ${ }^{1}$ Nigerian Building and Road Research Institute, Artisan Training and Pozzolana Centre, Bokkos, Plateau State, Nigeria \\ ${ }^{2}$ Nigerian Building and Road Research Institute, North Central Zonal Office, Jos, Plateau State, Nigeria
}

DOI: $10.36348 /$ sjet.2021.v06i04.006
*Corresponding author: Akanbi DO

Crushed Glass (CG) is a recycled material obtained from crushing waste glass and has been established as a partial replacement for cement in concrete. However, this research investigated the performance evaluation of using CG as a stabilizing agent to improve lateritic soil for road pavement layers. The CG powder used is $75 \mu \mathrm{m}$ and classified as type GE according to the new standard ASTMC 1866/C1866M-20 passed in early 2020 [10]. An A-7-6(11)/CL lateritic soil sample was studied and classified using AASHTO and Unified Soil Classification System (USCS). The soil was treated with CG in a stepped concentration of $0,2,4,6,8,10,12,14$ and $16 \%$ of weight of dry lateritic soil. Atterberg limit tests were carried out on the soil and soil-CG samples. The properties of compaction, California Bearing Ratio (CBR) and unconfined compressive strength (UCS) were also determined for the soil and soil-CG mixes using British Standard Light (BSL) compaction energy for the soil and soil-CG samples. Results show that, the liquid limit of the soil-CG mixture decreased with increase CG content, while the plastic limit increased with increase in CG content. The MDD and OMC also increased with increasing CG content, but up to $6 \%$ content, and then decreased with further increment in $\mathrm{CG}$ content. The soaked and unsoaked CBR values of the soil-CG mix are higher than the CBR value for the lateritic soil alone. These values are less than the specified minimum values of 30 and $80 \%$, respectively, for road subbase and base courses. This implies that CG cannot be used as a "stand-alone" additive for soil stabilization. Also, the UCS of the lateritic soil and soil-CG mix increased with curing age and increasing CG content, and the soil-CG have higher UCS values than the lateritic soil alone. For instance, the UCS of lateritic soil, soil-CG mix with $4 \%$ and $12 \%$ CG at 7 days curing age are 259.69, 300.09 and $388.39 \mathrm{kN} / \mathrm{m}^{2}$, respectively. The values are correspondingly $441.59,479.30$ and $599.91 \mathrm{KN} / \mathrm{m}^{2}$ at 28 days curing age, a trend that can be attributed to time-dependent strength gain action of the CG, which is a type GE pozzolana. Again, the UCS values of the soil-CG mixtures though increase with increase in both the curing age and $\mathrm{CG}$ content are less than $1710 \mathrm{kN} / \mathrm{m}^{2}$, minimum specified as a criterion for adequate soil stabilization with Ordinary Portland Cement (OPC). This further confirmed that CG, a waste, cannot be used as a "stand-alone" stabilization agent but as an additive to supplement OPC, thereby reducing the cost of stabilization.

Keywords: Laterite Crushed Glass, Stabilization, Compaction, Unconfined Compressive Strength, California Bearing Ratio.

Copyright ( $) 2021$ The Author(s): This is an open-access article distributed under the terms of the Creative Commons Attribution 4.0 International License (CC BY-NC 4.0) which permits unrestricted use, distribution, and reproduction in any medium for non-commercial use provided the original author and source are credited.

\section{INTRODUCTION}

Laterite is one of the major materials used as subbase and base courses of pavements layers. Subgrade soil is an integral part of pavement structures, which support the pavement and hence, must give adequate support and stability under adverse loading conditions [1]. The high incidence and frequency of road pavement failures have been of great concern to road engineers in developing countries like Nigeria. This has given rise to intensive research to find ways and means of improving the strength of the road bases
[2]. Osinubi [3] referred to soil stabilization as the alteration or control of any soil property. It covers not only the increase or decrease of any soil property but also the variation of any property with changes in environmental condition, namely moisture or pressure.

The stability of structures founded on soil depends on the large strength of the soil and its interaction with water [4]. It is, therefore, important to make soils deficient in strength, useful and meet geotechnical engineering design requirements. Over time, cement and lime have been the two main materials 
used for stabilizing soils. The most commonly used additive for soil modification or stabilization is ordinary Portland cement $[5,6]$. These materials have rapidly increased in price due to the sharp increase in the cost of energy since the 1970s [15], resulting in high cost of stabilization. Hence, the search for the use of potentially cost-effective industrial or agricultural waste materials, which are locally available, as stabilizing agents in order to improve the properties of poor soils which have become inevitable.

Crushed Glass (CG) is a material obtained by crushing waste glasses. It is a transparent material produced from silica, soda ash and calcium carbonate at high temperature. $\mathrm{CG}$ is used in a wide range of applications. One of its most significant contributions in construction is its usage as a form of aggregates and in the form of glass powder as a partial substitute of cement [7]. CG powder is a pozzolan and now has its own separate ASTM standard passed early in 2020. The new standard ASTM 1866/C1866M-20 describes two types of glass pozzolans. Type GE, which is a low alkali glass, is extremely effective for ASR mitigation, and type GS glass pozzolans which works well in concrete mix designs without reactive agents [8]. Pozzolana is a siliceous, or siliceous and aluminous material, which in itself possesses little or no cementitious value but, will in a finely divided or powdery form and in the presence of moisture, chemically react with calcium hydroxide at ordinary temperatures to form permanent, insoluble compounds possessing cementitious properties [9]. ASTM C618-78 [18] also described pozzolana as a siliceous and aluminous material that possess little or no cementitious value but, will in finely divided form and in the presence of moisture, chemically react with calcium hydroxide at ordinary temperatures to form cementitious compounds. An essential physical property of a cementing material that affects pozzolana's affinity for water is its fineness. The activity of pozzolanas is increased by fine grading. ASTM C618-78 [18] specification requires that the percentage passing sieve No. $200 \geq 85 \%$ is appropriate $[11,12]$.

The global demand for reduction of the increasingly high cost of waste disposal and costeffective soil stabilizers has led to intense global research towards economic utilization of wastes for engineering purposes. The safe disposal of industrial and agricultural waste products demand urgent and cost-effective solutions because of their debilitating effects on the environment and the health hazards that they constitute. Nearly all industrial activities lead to the depletion of natural resources, a process that results in the accumulation of by-products and/or waste materials. In most cases, there are problems associated with the disposal of these waste heaps [13].

This paper is aimed at studying the possibility of using crushed glass as a stabilizer to improve the strength of the lateritic soil, thereby reducing the cost of stabilization and eliminating the environmental hazards constituted by the broken glass (waste) materials. The objectives are to (i) determine the atterberg limits and strength properties (CBR and UCS) of the lateritic soil, (ii) determine the atterberg limits and the strength properties of the soil-CG mixes (for 2, 4, 6, 8, 10, 12, 14 and $16 \%$ contents of CG), (iv) reduce the environmental hazards of broken glass waste and hence (iii) evaluate and present the CG as a stabilizing agent in road pavement if found suitable.

\section{MATERIALS AND METHODS}

Lateritic soil samples, collected by the method of disturbed sampling, were obtained from a borrow pit located in Bokkos, Plateau State, Nigeria. The samples were collected at a depth of between 1.5 and $2.0 \mathrm{~m}$ corresponding to the $\mathrm{B}$ - horizon usually characterized by accumulation of material leached from the overlying A - horizon. The Crushed Glass were obtained from Jos, Plateau State, Nigeria, and crushed to the desired size of $75 \mu \mathrm{m}$. Sieving analysis, oxide composition, consistency, compaction, California Bearing Ratio, unconfined compressive strength tests were carried out on the soil samples with most of the tests carried out at the Nigerian Building and Road Research Institute Laboratory (NBRRI- Jos), Jos, Plateau State. Seven batches of $6 \mathrm{~kg}$ each, of the soil samples, were then taken and mixed with $2,4,6,8,10,12,14$ and $16 \%$ of CG content and the test repeated. All the tests were carried out in accordance with BS 1377 [19] and BS 1924 [20] procedures. Evaluation of the CG contents was carried out by comparing the strengths of lateritic soil/CG mixture with the sub base and base courses specified strengths for road pavement works.

\section{RESULTS AND DISCUSSION Results}

The properties and the particle size distribution curve of the lateritic soil are presented in Table 1 and Figure 1, respectively. Table 2 presents the oxide composition of the CG and the lateritic soil sample, while Tables 3 and 4 show the respective test results obtained for the wet sieve and dry sieve analyses of soil-CG mixtures. The atterberg limits results of the soil-CG mixture are shown in Table 5. Tables 6, 7 and 8 present the compaction, CBR and unconfined compressive strength tests results, respectively for the soil-CG mixtures. 
Table-1: Properties of the Natural Soil

\begin{tabular}{|l|c|}
\hline Property & \\
\hline Percentage passing BS No $200 \mu \mathrm{m}$ sieve & 58.8 \\
Natural Moisture Content, \% & 16.2 \\
Liquid Limit, \% & 43.4 \\
Plastic Limit, \% & 21.3 \\
Plasticity Index, \% & 22.1 \\
& 20.0 \\
Free Swell, \% & 2.59 \\
Specific Gravity & A-7-6(11) \\
AASHTO Classification [16] & CL \\
USCS & 1.62 \\
& 16.5 \\
Maximum Dry Density, Mg/m ${ }^{3}$ Optimum Moisture Content, & 259.69 \\
\% Unconfined Compressive Strength, kN/m ${ }^{2}$ & 3 \\
California Bearing Ratio, \% & Reddish-brown \\
\hline
\end{tabular}

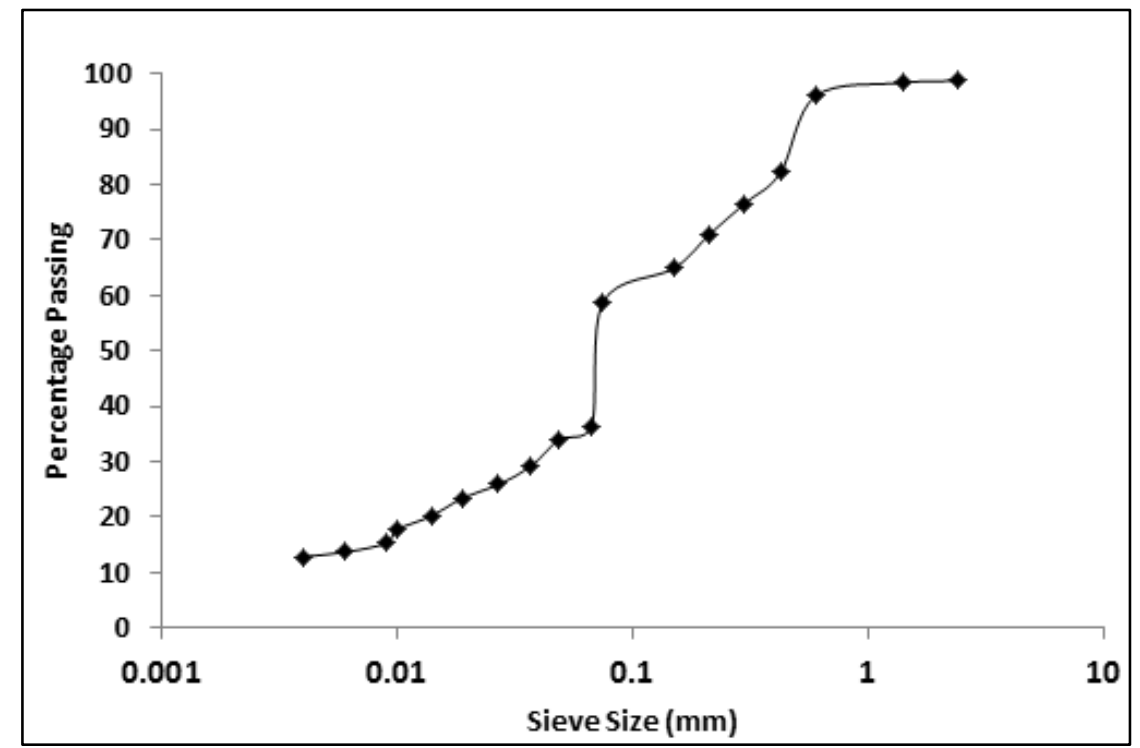

Fig-1: Particle Size Distribution for Natural Soil

Table-2: Oxide Composition of Crushed Glass and Lateritic Soil

\begin{tabular}{|l|l|l|}
\hline \multirow{2}{*}{ Oxide } & Concentration (\%) \\
\cline { 2 - 3 } & Crushed Glass & Lateritic Soil \\
\hline $\mathrm{CaO}$ & 21.38 & 0.28 \\
$\mathrm{SiO}_{2}$ & 60.0 & 35.60 \\
$\mathrm{Fe}_{2} \mathrm{O}_{3}$ & 0.35 & 24.0 \\
$\mathrm{Al}_{2} \mathrm{O}_{3}$ & 12.7 & 27.40 \\
$\mathrm{MnO}$ & 0.067 & 0.067 \\
$\mathrm{MnO}_{2}$ & - & 2.0 \\
$\mathrm{TiO}_{2}$ & - & - \\
$\mathrm{K}_{2} \mathrm{O}$ & 0.07 & - \\
$\mathrm{PbO}$ & - & - \\
$\mathrm{Na}$ & 0.78 & - \\
$\mathrm{MgO}$ & 2.90 & - \\
$\mathrm{SO}$ & $<0.1$ & 0.85 \\
$\mathrm{LOI}$ & $<0.1$ & 14.6 \\
\hline
\end{tabular}

From the oxide composition result, the lateritic soil and the crushed glass both has a good pozzolanic properties (summation of silicon oxide + iron oxide + aluminum oxide $>70 \%$ ). And the specific gravities of crushed glass and lateritic soil are 3.77 and 2.59 respectively. 
Table-3: Wet Sieve Analysis of Soil-IOT Mixture

\begin{tabular}{|l|l|l|l|l|l|l|l|l|l|}
\hline $\begin{array}{l}\text { Sieve } \\
\text { Size }\end{array}$ & 0\% CG & $\mathbf{2 \%}$ CG & $\mathbf{4 \%}$ CG & $\mathbf{6 \%}$ CG & $\mathbf{8 \%}$ CG & $\begin{array}{l}\mathbf{1 0 \%} \\
\text { CG }\end{array}$ & $\begin{array}{l}\mathbf{1 2 \%} \\
\text { CG }\end{array}$ & $\begin{array}{l}\mathbf{1 4 \%} \\
\text { CG }\end{array}$ & $\begin{array}{l}\mathbf{1 6 \%} \\
\text { CG }\end{array}$ \\
\hline 3.175 & 100 & 100 & 100 & 100 & 100 & 100 & 100 & 100 & 100 \\
\hline 2.4 & 98.8 & 95.5 & 98.5 & 96.8 & 97.0 & 97.2 & 98.15 & 98.4 & 98.3 \\
\hline 1.4 & 98.4 & 95.0 & 97.9 & 96.1 & 96.1 & 96.6 & 97.6 & 97.7 & 97.65 \\
\hline 0.6 & 96.0 & 93.0 & 95.5 & 93.6 & 92.7 & 93.2 & 94.75 & 94.6 & 94.65 \\
\hline 0.425 & 82.2 & 80.9 & 81.3 & 78.9 & 76.9 & 77.8 & 78.1 & 78.05 & 77.75 \\
\hline 0.3 & 76.6 & 75.0 & 75.7 & 73.7 & 70.9 & 70.9 & 71.1 & 70.9 & 70.7 \\
\hline 0.212 & 71.0 & 69.4 & 69.9 & 67.1 & 64.4 & 64.5 & 64.1 & 63.9 & 63.65 \\
\hline 0.15 & 64.9 & 63.2 & 64.2 & 60.1 & 58.3 & 57.2 & 57.65 & 57.8 & 57.05 \\
\hline 0.075 & 58.8 & 56.8 & 56.8 & 52.0 & 50.7 & 50.4 & 50.35 & 51 & 50.2 \\
\hline 0.067 & 36.5 & 36.8 & 32.5 & 30.4 & 30.4 & 28.2 & 28.06 & 28.18 & 26.51 \\
\hline 0.049 & 34.1 & 31.2 & 31.0 & 25.8 & 25.9 & 25.3 & 25.89 & 25.27 & 23.63 \\
\hline 0.037 & 29.2 & 28.8 & 28.6 & 22.7 & 23.7 & 23.1 & 21.55 & 23.09 & 20.74 \\
\hline 0.027 & 25.9 & 25.5 & 24.7 & 20.5 & 20.7 & 18.8 & 18.66 & 19.46 & 18.58 \\
\hline 0.019 & 23.5 & 21.5 & 21.6 & 18.2 & 17.7 & 15.9 & 15.77 & 16.56 & 14.98 \\
\hline 0.014 & 20.2 & 18.3 & 18.5 & 15.1 & 14.8 & 13.7 & 13.6 & 14.38 & 13.54 \\
\hline 0.01 & 17.8 & 15.9 & 16.2 & 12.8 & 12.5 & 12.2 & 11.43 & 12.2 & 12.1 \\
\hline 0.009 & 15.3 & 14.3 & 14.6 & 11.3 & 11.0 & 10.8 & 9.98 & 10.75 & 10.66 \\
\hline 0.006 & 13.7 & 12.7 & 13.1 & 10.5 & 9.5 & 9.3 & 9.26 & 10.02 & 9.94 \\
\hline 0.004 & 12.9 & 11.9 & 12.3 & 9.0 & 8.8 & 8.6 & 8.53 & 9.3 & 9.22 \\
\hline
\end{tabular}

Table-4: Dry Sieve Analysis of Soil-CG Mixture

\begin{tabular}{|c|c|c|c|c|c|c|c|c|c|}
\hline \multirow{2}{*}{$\begin{array}{l}\text { Sieve } \\
\text { size }\end{array}$} & \multicolumn{9}{|c|}{ Percent Passing } \\
\hline & $0 \% \mathrm{CG}$ & $2 \% \mathrm{CG}$ & $4 \% \mathrm{CG}$ & $6 \% \mathrm{CG}$ & $8 \% \mathrm{CG}$ & $\begin{array}{l}10 \% \\
\text { CG }\end{array}$ & $\begin{array}{l}12 \% \\
\text { CG }\end{array}$ & $\begin{array}{l}14 \% \\
\text { CG }\end{array}$ & $\begin{array}{l}16 \% \\
\text { CG }\end{array}$ \\
\hline 3.175 & 100 & 100 & 100 & 100 & 100 & 100 & 100 & 100 & 100 \\
\hline 2.4 & 81.15 & 77.75 & 79.45 & 71.05 & 78.1 & 83.8 & 82.3 & 80.4 & 78.9 \\
\hline 1.4 & 73.25 & 72.2 & 72.35 & 66.6 & 72.05 & 76.35 & 74.35 & 73.8 & 73.45 \\
\hline 0.6 & 57.2 & 57.35 & 58.3 & 53.35 & 56.3 & 60 & 57.75 & 61 & 60.3 \\
\hline 0.425 & 32.95 & 34.25 & 35.2 & 30.9 & 33.55 & 36.05 & 34.35 & 37.5 & 36.05 \\
\hline 0.3 & 27.3 & 27.9 & 28.6 & 24.1 & 28.35 & 29.3 & 28.05 & 30.65 & 30.2 \\
\hline 0.212 & 22.35 & 22.5 & 22.8 & 18.8 & 22.55 & 23.85 & 21.45 & 24.65 & 23.05 \\
\hline 0.15 & 16.75 & 17 & 16.35 & 13.25 & 17.1 & 17.5 & 15.5 & 19.55 & 17.7 \\
\hline 0.075 & 5.1 & 4.75 & 5 & 5.55 & 5.15 & 6.45 & 4.8 & 5.6 & 5.55 \\
\hline
\end{tabular}

Table-5: Atterberg Limits of Soil-CG Mixture

\begin{tabular}{|l|l|l|}
\hline CG Content (\%) & Liquid Limit (\%) & Plastic Limit (\%) \\
\hline 0 & 43.4 & 11.43 \\
\hline 2 & 47 & 11.79 \\
\hline 4 & 45.2 & 11.93 \\
\hline 6 & 44.9 & 12.14 \\
\hline 8 & 43.5 & 12.5 \\
\hline 10 & 43 & 12.64 \\
\hline 12 & 42.6 & 12.86 \\
\hline 14 & 42.6 & 13.57 \\
\hline 16 & 41.6 & 14.29 \\
\hline
\end{tabular}

Table-6: Maximum Dry Density and Optimum Moisture Content of Soil-CG Mixture

\begin{tabular}{|l|l|l|}
\hline CG Content $\mathbf{( \% )}$ & MDD $\left(\mathbf{M g} / \mathbf{m}^{3}\right)$ & OMC $(\%)$ \\
\hline 0 & 1.62 & 16.5 \\
\hline 2 & 1.74 & 17 \\
\hline 4 & 1.76 & 17.5 \\
\hline 6 & 1.78 & 18 \\
\hline 8 & 1.77 & 17 \\
\hline
\end{tabular}




\begin{tabular}{|l|l|l|}
\hline 10 & 1.76 & 16.5 \\
\hline 12 & 1.76 & 15.5 \\
\hline 14 & 1.75 & 15 \\
\hline 16 & 1.75 & 14.5 \\
\hline
\end{tabular}

Table-7: CBR of Soil-Crushed glass Mixture

\begin{tabular}{|l|l|l|}
\hline \multirow{2}{*}{ CG Content (\%) } & \multicolumn{2}{|l|}{ CBR(\%) } \\
\cline { 2 - 3 } & Unsoaked & 24 hrs Soaking \\
\hline 0 & 10.52 & 3.01 \\
\hline 2 & 11.02 & 3.76 \\
\hline 4 & 11.71 & 4.01 \\
\hline 6 & 12.46 & 4.91 \\
\hline 8 & 12.53 & 6.80 \\
\hline 10 & 16.62 & 7.18 \\
\hline 12 & 18.13 & 5.51 \\
\hline 14 & 20.05 & 5.01 \\
\hline 16 & 15.86 & 3.51 \\
\hline
\end{tabular}

Table-8: Unconfined Compressive Strength of Soil-Crushed Glass Mixture

\begin{tabular}{|l|l|l|l|l|}
\hline \multirow{2}{*}{ CG Content (\%) } & \multicolumn{4}{|l|}{ UCS $\left(\mathbf{k N} / \mathbf{m}^{\mathbf{2}}\right)$} \\
\cline { 2 - 5 } & \multicolumn{4}{|l|}{ Age (Days) } \\
\cline { 2 - 5 } & $\mathbf{7}$ & $\mathbf{1 4}$ & $\mathbf{2 8}$ & $\mathbf{7 d a y s}$ curing, 7 days soaking \\
\hline 0 & 259.69 & 263.30 & 441.59 & 25.72 \\
\hline 2 & 281.23 & 284.00 & 468.38 & 27.02 \\
\hline 4 & 300.90 & 307.13 & 479.30 & 29.95 \\
\hline 6 & 331.86 & 369.81 & 484.77 & 49.29 \\
\hline 8 & 345.73 & 381.59 & 501.16 & 33.75 \\
\hline 10 & 373.80 & 434.47 & 514.34 & 31.85 \\
\hline 12 & 388.39 & 454.60 & 599.91 & 29.07 \\
\hline 14 & 409.27 & 471.72 & 607.96 & 26.30 \\
\hline 16 & 410.83 & 482.94 & 698.33 & 20.90 \\
\hline
\end{tabular}

\section{DISCUSSIONS}

Table 9 presents the evaluation of crushed glass properties and content in the lateritic soil.

Table-9: Evaluation of Crushed Glass and Soil-CG Properties

\begin{tabular}{|l|l|l|l|l|l|}
\hline Property & Laterite & $\begin{array}{l}\text { Soil-CG } \\
\mathbf{2 - 1 6 \%} \text { CG }\end{array}$ & $\begin{array}{l}\text { Subbase } \\
\text { Course }\end{array}$ & $\begin{array}{l}\text { Base } \\
\text { Course }\end{array}$ & Remarks \\
\hline $\begin{array}{l}\text { Liquid limit } \\
(\%)\end{array}$ & 43.4 & $41.6-47.0$ & $\leq 35$ & $\leq 35$ & $\begin{array}{l}\text { Soil treated CG not suitable as both } \\
\text { subbase and base material }\end{array}$ \\
\hline $\begin{array}{l}\text { Plastic limit } \\
(\%)\end{array}$ & 21.3 & $25.7-30.4$ & $\leq 25$ & $\leq 25$ & $\begin{array}{l}\text { Soil treated CG not suitable as both } \\
\text { subbase and base material }\end{array}$ \\
\hline MDD $\left(\mathrm{Mg} / \mathrm{m}^{3}\right)$ & 1.62 & $1.74-1.78$ & $\geq 1.8$ & $\geq 1.8$ & $\begin{array}{l}\text { Soil treated CG not suitable as both } \\
\text { subbase and base material }\end{array}$ \\
\hline OMC (\%) & 16.5 & $14.5-18.0$ & $6-7$ & $6-7$ & $\begin{array}{l}\text { Soil treated CG not suitable as both } \\
\text { subbase and base material }\end{array}$ \\
\hline $\begin{array}{l}\text { CBR }(\%) \\
(\text { Unsoaked) }\end{array}$ & 10.52 & $11.02-20.05$ & $\geq 30$ & $\geq 80$ & $\begin{array}{l}\text { Soil treated CG not suitable as both } \\
\text { subbase and base material }\end{array}$ \\
\hline $\begin{array}{l}\text { CBR }(\%) \\
(\text { Soaked })\end{array}$ & 3.01 & $3.51-7.18$ & $\geq 15$ & $\geq 55$ & $\begin{array}{l}\text { Soil treated CG not suitable as both } \\
\text { subbase and base material }\end{array}$ \\
\hline $\begin{array}{l}\text { 28-day UCS } \\
\left(\mathrm{kN} / \mathrm{m}^{2}\right)\end{array}$ & 441.59 & $468.38-698.33$ & $\geq 1710$ & $\geq 1710$ & $\begin{array}{l}\text { Soil treated CG not suitable as both } \\
\text { subbase and base material }\end{array}$ \\
\hline
\end{tabular}

Results show that the liquid limit of the lateritic soil is $43.4 \%$, while that for the $\mathrm{CG}$ mixtures are in the range $41.6-47.0 \%$. The corresponding plastic limits are $21.3 \%$ and $25.7-30.4 \%$. Also, it was observed that the liquid limit of the soil-CG mixture decreased with an increase in $\mathrm{CG}$ content. On the other hand, the plastic limit increased with an increase in CG content.

The MDD and OMC of the soil-CG mix, in the ranges of $1.74-1.78 \mathrm{Mg} / \mathrm{m}^{3}$ and $14.5-18.0 \%$ respectively, are all higher than the corresponding 
values of $1.62 \mathrm{Mg} / \mathrm{m}^{3}$ and $16.5 \%$ for lateritic soil. In addition, results show that both the MDD and OMC increased with increasing CG content up to $6 \%$ content and then decreased with further increase in CG content. In the same manner, the respective CBR (soaked and unsoaked) values for the soil-CG mix, in the ranges of $3.51-7.18 \%$ and $11.02-20.05 \%$, are higher than the corresponding values of 3.01 and $10.52 \%$ for the lateritic soil alone. However, the soaked and unsoaked CBR values for the soil-CG mix increased with $C G$ content from 2-10\%. Further increase in CG content showed a decrease in the CBR values. These values are less than the specified values of 30 and $80 \%$, respectively for subbase and base courses. This implies that iron ore tailing cannot be used as a 'stand-alone' additive for soil stabilization to be used for subbase and base courses in road pavement works.

The unconfined compressive strengths of the lateritic soil and the soil-CG mixture increased with age and increasing CG content, and the soil treated with CG have higher values than the lateritic soil alone. For instance, the unconfined compressive strengths of lateritic soil, soil-CG mix with $4 \%$ and $12 \% \mathrm{CG}$ at 7 days curing age are 259.69, 300.09 and $388.39 \mathrm{kN} / \mathrm{m}^{2}$, respectively. The values are correspondingly 441.59 , 479.30 and $599.91 \mathrm{kN} / \mathrm{m}^{2}$ at 28days. The trend of increased compressive strength with curing age can be attributed to time-dependent strength gain action of the pozzolana. However, the unconfined compressive strength of the soil-CG mixture when cured for 7 days and then soaked for another 7 days increased from $2 \%$ $6 \%$ CG content but decreased with further increase in CG content. Again, the UCS values of the lateritic soil and soil CG mix, though increased with age and CG content, are less than $1710 \mathrm{kN} / \mathrm{m}^{2}$ specified by TRRL [14] as the criterion for adequate soil stabilization with Ordinary Portland Cement, further indicating that CG cannot be used as a 'stand-alone' additive for soil stabilization.

\section{CONCLUSIONS AND RECOMMENDATIONS}

The study aimed at investigating the strength improvement of poor lateritic soil using crushed glass (waste) as a stabilizing agent for subbase and base course of road pavement layers. The following conclusions were drawn:

(i) The lateritic soil is of the A-7-6(11) AASHTO classification with a moisture content of $16.24 \%$, liquid limit of $43.4 \%$, plastic limit of $21.33 \%$, a specific gravity of 2.59 and CBR of $10.52 \%$, indicating a poor soil that is unfit as material for road pavement works.

(ii) The crushed glass contains large amount of silicate, ferrous and aluminate, which are major components for cement production, and hence a cementitious material with binding properties.

(iii) The physical properties of the soil-CG mixture improved with an increase in CG treatment. For instance, the liquid limit values for the lateritic soil alone are $43.3 \%$ and $47 \%$, respectively, while the corresponding values for soil-CG mixture from 2 - $16 \% \mathrm{CG}$ content increased from 41.6 $47.0 \%$ and $25.7-30.4 \%$, respectively.

(iv) The MDD and OMC of the soil-CG mixture increased with an increase in CG contents of 2 $6 \%$, and then decreased with further increase in CG content. Also, the MDD of soil-CG mixtures are greater than the MDD of the lateritic soil, which implies that the CG has an impact on the soil strength, with ultimate strength occurring at 6\% CG content.

(v) The respective soaked and unsoaked CBR values of the soil-CG mixture, in the ranges $3.51-7.81 \%$ and 11.02-20.05, are higher than the corresponding values of 3.01 and $10.52 \%$ for the lateritic soil alone, but less than 30 and $80 \%$ specified for road subbase and base courses. This implies that CG can only be an additive to other stabilizing agents for the improvement of road pavement materials.

(vi) The UCS of the lateritic soil and the soil-CG mixture increased with curing age and increasing CG content. In addition, CG-treated soils have higher UCS values than the lateritic soil. The trend of increased UCS with curing age can be attributed to time-dependent strength gain action of the pozzolana.

(vii) The UCS values for soaked samples are far lower than the corresponding values for the unsoaked for all curing ages, and more so UCS of the soil-CG mix subjected to 7days curing followed by 7 days soaking, increased with an increase in CG content to reach a maximum value of $49.29 \mathrm{kN} / \mathrm{m}^{2}$ at $6 \%$, decreased with further increase in CG content. The loss in strength of soil was due to the ingress of water.

(viii) For all the properties measured, the soil-CG mixture falls short of the properties required for materials used as pavement layers. However, the CBR and UCS values of the soil-CG are far greater than the corresponding values of the laterite alone. Hence, the crushed glass cannot be used as a "stand-alone" or single stabilizer of soils for pavement layers as a result of it being a type GE pozzolana (class $\mathrm{N}$ ) which is a low alkali. It can therefore be used as a modifier or an admixture in lime or cement stabilization of poor lateritic soil, thereby reducing the cost of lime or cement required in the stabilization process.

\section{It is, therefore, recommended that}

Crushed Glass (CG) should be used as admixture in lime or cement stabilization of lateritic soils, requiring improvement. This will reduce the cost of stabilizing agent that will be required in improving the properties of soils for pavement works.

\section{REFERENCES}


1. Akanbi, D.O., \& Job, F.O. (2014). "Suitability of Black Cotton (Clay) Soil Stabilized with Cement and Quarry Dust for Road Bases and Foundations" Electronic Journal of Geotechnical Engineering, 6305-6313

2. Eze-Uzomaka, O.J., \& Agbo, D. (2010). "Suitability of Quarry Dust as Improvement to Cement Stabilized-Laterite for road Bases", Electronic Journal of Geotechnical Engineering,1053-1066

3. Osinubi, K.J. (1995). "Lime modification of black cotton soils". Spectrum Journal, 2(1)2, 112-122.

4. Alhassan, M. (2008b). "Permeability of Lateritic Soil Treated With Lime and Rice Husk Ash" Assumption University Journal of Technology, 12(2): 115-120.

5. Chu, S., \& Kao, H. (1993). "A Study of Engineering Properties of a Clay Modified by Fly Ash Slag in Fly Ash for Soil Improvement" Geotechnical Special Publications, K. D Sharp (ed.) Geotechnical Engineering. Division of ASCE, 36, 88-89

6. Hausmann, M.N. (1990). "Engineering Principles of Ground Modification", McGraw- Hill, New York

7. Gautam, P., Dhokale, B., Mobin, S. M., \& Misra, R. (2012). Ferrocenyl BODIPYs: synthesis, structure and properties. RSC advances, 2(32), 12105-12107.

8. Nafisa, T., Norsuzailina, M.S., Rabin, T., Delsye, T.C., \& Ibrahim, Y. (2016). "Pozzolanic Properties of Glass Powder in Cement Paste. Iranian Journal of Science and TechnologyTransaction of Civil Engineering 7(2): 75-81.

9. Moxie-Intl. (2006). "Definition of Pozzolan", <http://www.moxieintl.com/glossary.htm> 31th March, 2008

10. ASTM 1866/ C1866M-20. (2020). "Standard Specification for Ground-Glass Pozzolan for use in Concrete". American Society for Testing and
Materials, Pheladephia.

11. Lea, F.M. (1956). "The Chemistry of Cement and Concrete", $2^{\text {nd }}$ edition, Edward Arnold (published) Ltd., London

12. Smith, R.G. (1992). "Alternatives to Ordinary Portland Cement", British Building Society Journal, 25, 1-17

13. Oriola, F., \& Moses, G. (2010). "Groundnut Shell Ash Stabilization of Black Cotton Soil", Electronic Journal of Geotechnical Engineering, 15: 415-428

14. TRRL. (1977). "A guide to the Structural Design of Bitumen Surfaced Roads in Tropical and Subtropical Countries', Transport and Road Research Laboratory, Road Note 31, H. M. S. O., London

15. Neville, A.M. (2000). "Properties of Concrete", $4^{\text {th }}$ ed. Pearson Education Asia Limited, Kuala Lumpur, Malaysia

16. AASHTO. (1986). "Standard Specification for Transport Materials and Methods of Sampling and Testing" $14^{\text {th }}$ Edition, American Association of State Highway and Transport Officials (AASHTO), Washington, D.C

17. ASTM. (1992). "Annual Book of Standards", Vol. 04.08, American Society for Testing and Materials, Pheladephia

18. ASTM C618-78. (1978). "Specification for Fly Ash and Raw Calcined Natural Pozzolana For use as a Mineral Admixture in Portland Cement Concrete", American Society for Testing and Materials,Pheladephia

19. BS 1377. (1990). "Method of Testing Soil for Civil Engineering Proposal", British Standard Institute (BSI) London

20. BS 1924. (1990). "Methods of Tests for Stabilized Soils", British Standard Institute (BSI) London

21. Federal Ministry of Works, Nigerian General Specifications. (1997). "Roads and Bridges", Abuja, Nigeria. 